\title{
Population dynamics of the coconut caterpillar, Opisina arenosella Walker \\ (Lepidoptera: Xyloryctidae), in Sri Lanka
}

\author{
P. A. C. R. PERERA, \\ Coconut Research Institute, Lunuwila, Sri Lanka
}

M. P. HASSELL and H. C. J. GODFRAY*

Department of Pure and Applied Biology, Imperial College at Silwood Park, Ascot, Berkshire,

SL5 7PY, UK

\begin{abstract}
Opisina arenosella Walker is a defoliating pest of coconut in Sri Lanka. A first attempt was made to understand its population dynamics. Analysis of records of population outbreaks throughout the country from 1965 to 1985 revealed cycles in the population of approximately one generation period, giving the population the appearance of partially discrete generations. There was also evidence for longer cycles of six-month period. Outbreaks occurred throughout the coconut-growing regions of Sri Lanka, and the numbers of outbreaks per year in different provinces were sometimes correlated, indicating a common, probably climatic, triggering mechanism. Parasitism remained high throughout the outbreaks and there was some evidence that pupal parasitism increased towards the end of an outbreak. A working hypothesis that explains the population dynamics of $O$. arenosella and the origin of outbreaks is presented.
\end{abstract}

\section{INTRODUCTION}

Opisina arenosella Walker (= Nephantis serinopa Meyrick) is an importanı defoliating, outbreak pest of coconut palms in Sri Lanka. It is also recorded from India (Nirula, 1956), Burma (Ghosh, 1924) and Bangladesh (Alam, 1962) (a record from Indonesia (Davis and Sudasrip, 1982) is erroneous). Damage to coconuts in Sri Lanka was first noted in the middle of the 19th century (Green, 1898), and outbreaks are now most frequently recorded from coastal districts of the Eastern, Western. North Western and Southern Provinces (Perera, 1987). The major literature on this pest includes reviews by Jayaratnam (1941), Mohamed et al. (1982), Nirula (1956) and Ramachandran et al. (1979).

A variety of cultural, biological and chemical control measures have been employed against the pest, and artificial defoliation experiments (Perera, 1987) confirm that moderate to high densities of $O$. arenosella do indeed cause economic yield loss. Caterpillar infestations are chiefly confined to the lower fronds, and it has

This paper is reprinted from the Bulletin of Entomological Research /78 (3); 479.492] with the kind permission of the Commonwealth Agricultural Bureau International, Wallingford. Oxon.. UK. 


\section{Population Dynamics of the Coconut Caterpillar}

been suggested that these fronds should be cut down and burnt (Hutson, 1922; Rohitha, 1982). This method, however, has also been criticized due to the effect on parasitoids and predators (de Mel, 1927). There has been a long history of both classical and augmentative biological control attempts in Sri Lanka, and a number of parasitoid species have been introduced from India. Cock \& Perera (1987) reviewed the biological control of $O$. arenosella and discussed possible new developments. The recent discovery of a sex pheromone produced by females of $O$. arenosella offers the possibilites of new control techniques (P. S. Beevor \& J. D. Mumford, pers. comm.). The difficulties of applying insecticides to the crowns of tall palms has hindered the use of chemical control methods, although a number of successes with different pesticides have been reported (Nirula, 1956; Sundaramurthy \& Santhanakrishan, 1979). Recently, experiments with systemic insecticides applied through trunk injection (Kanagaratnam, 1976; Nadarajan \& Channabasavanna, 1981; Kanagaratnam \& Pinto, 1985) or through petiolar wells (P. A. C. R. Perera, R. Mahindapala \& U. Pethiyagoda, unpublished) have produced promising results.

$O$. arenosella is present at low endemic densities over much of the coconut-growing regions of Sri Lanka and only irregularly becomes a pest. A knowledge of why low density populations erupt, and what processes limit the duration of outbreaks, will obviously assist in the planning and implementation of control measures. The aim of this paper is to describe a first attempt to understand the population dynamics of $O$. arenosella based on long-term population monitoring by the Coconut Research Institute (CRI) of Sri Lanka.

\section{Biology of Opisina arenosella}

Females of $O$. areno. Ila lay their eggs in small groups on the under surface of coconut leaflets. Eggs are 1.equently deposited in the vicinity of feeding larvae, and it has been suggested that this results in the slow spread of outbreaks to peripheral, uninfested trees (Perera, 1987). The larvae usually have five instars and feed on the under surface of coconut leaves, at first gregariously, but then singly, consuming the lower epidermis and mesophyll but leaving the upper epidermis intact. The upper surface of the leaf has a characteristic scorched appearance where caterpillars have fed. The larvae construct a gallery of silk and frass into which they retreat if disturbed. There is evidence that some early larval and egg mortality is caused by cannibalism by older larvae. Pupation takes place within the larval gallery. Adults are frequently found during the day resting on the under surface of leaves of palms damaged by the pest. The moth flies at night, but little is known of its dispersal abilities.

The egg stage lasts on average three days and the five larval instars last six, seven, seven, five and ten days, respectively (see Perera (1987) for further details). Although there are normally five instars, up to eight have been recorded in the laboratory when the larvae are stressed (the supernumerary instars would be indistinguishable from the fifth instar in the field). The pupal stage lasts an average of eight days, and the total length of the preadult life-cycle is thus approximately 46 days. Females placed individually in field cages lived on average for 7.1 days (s.e. \pm $0.2, n=9$ ) during which they laid 152 eggs (s.e. \pm 26 ), leaving an average of 69 eggs (s.e. \pm 21 ) unlaid. Under ambient laboratory conditions, a single $O$. arenosella larva consumes $1823 \mathrm{~mm}^{2}$ (s.e. \pm 100 ) of coconut leaf (Perera, 1987). Apart from coconut, $O$. arenosella is known to feed on a number of other palm species (Dharmaraju. 1963; Lever, 1969), particularly palmyra, Borassus flabellifer. Outbreaks have been 
exceptionally recorded from date palm (Butani, 1975) and, dubiously, from banana (Manjunath, 1985). Talati \& Kapadia (1984) compare the performance of larvae on a number of palm species.

The more important parasitoids attacking $O$. arenosella larvae are the solitary endoparasitoid Eriborus trochanteratus Morley (Hymenoptera: Ichneumonidae) and the gregarious ectoparasitoids Goniozus nephantidis (Muesebeck) (Hymenoptera: Bethylidae) and Bracon Brevicornis Wesmael (Hymenoptera: Braconidae). The chief pupal parasitoid is Brachymeria nephantidis Gahan (Hymenoptera: Chalcididae). A number of other parasitoids are known, and the complete parasitoid complex is reviewed by Cock \& Perera (1987).

Birds, ants, spiders and mites have all been recorded feeding on $O$. arenosella, although their role in the dynamics of the pest is unknown. Among insect predators, species of Anthocoridae, Reduviidae and Carabidae have been recorded attacking $O$. arenosella (Cock \& Perera, 1987). A number of insect pathogens is known to infect this species in the laboratory, although the only record of a disease causing widespread mortality in the wild is of a nuclear polyhedrosis virus affecting larvae in Kerala, India (Philip et al., 1982).

\section{METHODS}

$O$. arenosella was declared a pest in Sri Lanka in 1924 when it became a legal requirement to report any outbreaks to the agricultural authority (since 1956 to the Coconut Research Institute (CRI). Records are forwarded to the CRI headquarters by a network of field officers. The location and duration of these outbreaks between 1963 and 1985 are analysed below.

$O$. arenosella populations were sampled at six sites for different periods of time and with different frequencies between 1963 and 1985. A summary of the sampling periods, with the names of the sites $(A-F)$, is given in Table 1 and their locations in Sri Lanka in Fig. 1. The data from the six sites are of three types:

TABLE I. The names, location and times of sampling of the sites used

\begin{tabular}{llllr}
\hline Site & Estate name & sampling period & $\begin{array}{l}\text { Frequency } \\
\text { of sampling }\end{array}$ & $\begin{array}{r}\text { Duration } \\
\text { (months) }\end{array}$ \\
\hline A & Goluwapokuna & Apr. 1982-July. 1983 & Weekly & 16 \\
B & Horakelle & May 1983-Jan. 1985 & Weekly & 21 \\
C & Dickovita & Jun. 1963-Jan. 1973 & Monthly & 115 \\
D & Delature & May 1980-Dec. 1985 & Bimonthly & 68 \\
E & Siyambalagasara & Jan. 1981-Dec. 1985 & Bimonthly & 60 \\
F & Ambalangoda & Jan. 1981-Aug. 1985 & Bimonthly & 54 \\
\hline
\end{tabular}

1) Weekly samples were taken at sites A and B over short periods of up to 21 months with sampling initiated at the peak of an outbreak.

2) Monthly samples were taken at Site $C$ over a ten-year period.

3) Bimonthly sampling was carried out at Sites D, E and F over a 4-5 year period.

Sites C-F were chosen because these estates had a history of $O$. arenosella attack. Sites A-D and F are in the wet zone of Sri Lanka, while Site $E$ is on the boundary of the wet and dry zones. Full details and maps of the sites are given in Perera (1987). 


\section{Population Dynamics of the Coconut Caterpillar}

Sampling consisted of 20 leaflets taken at random from the lower fronds of randomly chosen palms. The number of palms that were sampled per site depended on the size of the infestation and varied from 5 (Site C) to 25 (Sites A \& F). Preliminary studies (Perera, 1987) showed that the highest densities of pests were found on fronds 12-14 (fronds are numbered chronologically with the youngest, fully-opened frond designated 1). Samples were primarily taken from these fronds, although some additional samples were sometimes taken from older fronds.

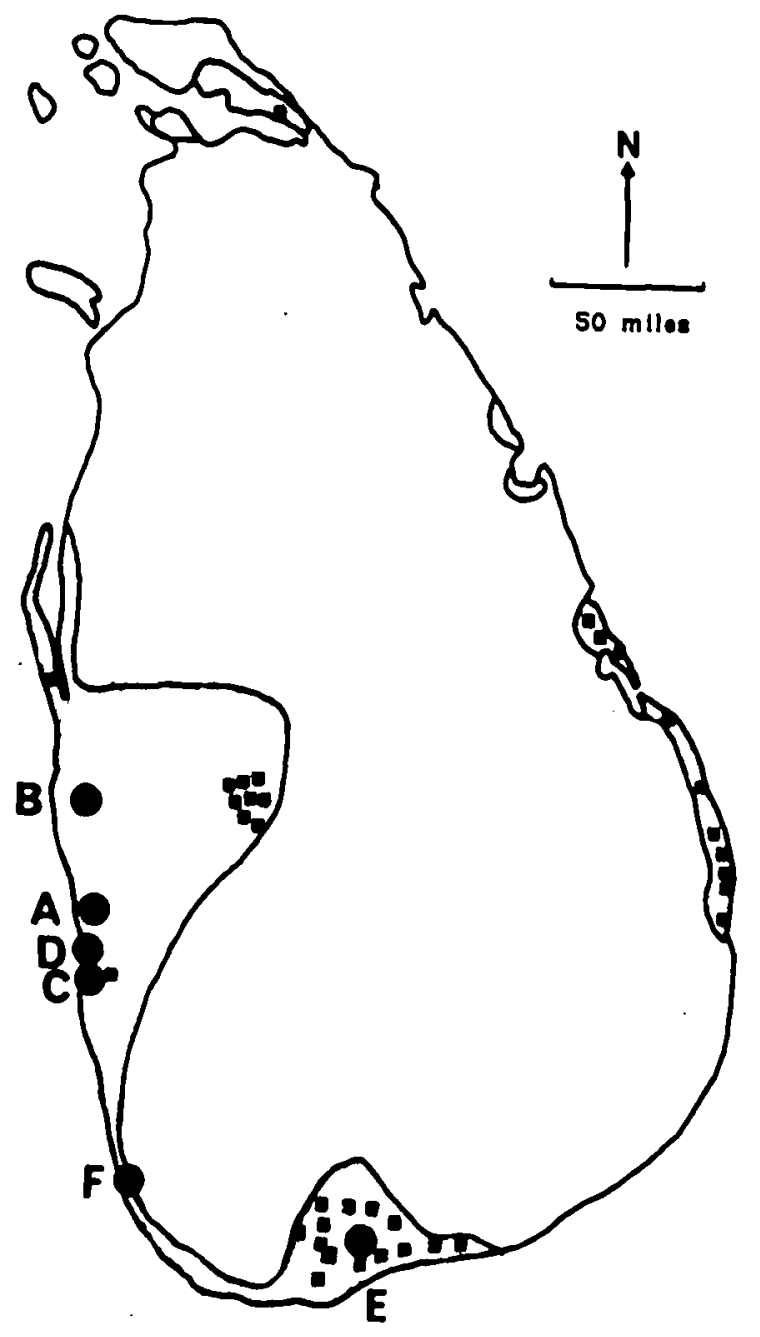

Fig. 1. - Map of Sri Lanka showing the major coconut-growing areas (shaded). Estates reporting more than one outbreak of Opisina arenosella in the period 1965-85 (in the Eastern Province to 198.3) are shown as squares. The sampling sites A-F, listed in Table I, are also shown (large circles). 


\section{RESULTS}

Survey of outbreaks reported to CRI

Approximately 400 outbreaks of $O$. arenosella were reported to the CRI on 159 estates between 1965 and 1985. The majority of these were in the Eastern, Southern and North-Western Provinces and lasted from a single generation to several years (Table II), with the majority (74\%) experiencing only a single attack (Table III). The location of estates that recorded more than one pest outbreak is shown on Fig.l.

The numbers of outbreaks that occurred per year is shown in Fig.2. There is considerable variability between years in this figure although, as shown in Table IV, the numbers of outbreaks in the Southern and Eastern Provinces are highly correlated. This suggests that some underlying factor, probably climatic, is acting over a wide geographical range and may be responsible for triggering outbreaks.

\section{Sites $A$ and $B$, weekly samples over 16-21 months}

The pattern of population changes at Sites A and B is shown in Figs $3 \& 4$. The numbers of $O$. arenosella in the different stages of the life cycle are shown separately. The generations of the pest are clearly separated, and the population structure approaches discrete generations with a period of approximately eight weeks (= one generation interval). In both sites, sampling began at the peak of an outbreak, after which populations declined to endemic levels. There was no evidence that the discreteness of the generations became weaker as the population declined, although the sampling regime was not able to reveal population structure at low densities.

Both larval and pupal parasitism showed two distinctive patterns. Firstly, parasitism was clearly acting in a delayed manner, being out of phase with the generation cycles in the hosts (Fig.5). Secondly, parasitism tended to remain high, or perhaps increase, during the course of an outbreak as the host population levels declined. It should thus have tended to act as an inverse density-dependent factor in relation to average host population levels throughout the course of an outbreak. There is some, albeit inconclusive, evidence for this from pupal parasitism at Site A (Fig.6). The main difference between the patterns of larval and pupal parasitism lay in the much higher levels of pupal than larval parasitism (Fig.5).

TABLE II. The numbers of oubreaks of Opisina arenosella of differen durations in $1965-85$

Duration of outbreak (months)

\begin{tabular}{lrrrr}
\hline Province & $1-4$ & $5-8$ & $>8$ & Totals \\
Southern & 53 & 37 & 32 & 122 \\
Eastern & 55 & 68 & 56 & 179 \\
North-Western & 42 & 27 & 17 & 18 \\
Western & 18 & 10 & 3 & 31 \\
Others & 1 & 0 & 2 & 3 \\
\hline Totals & 169 & 142 & 110 & 421 \\
\hline
\end{tabular}




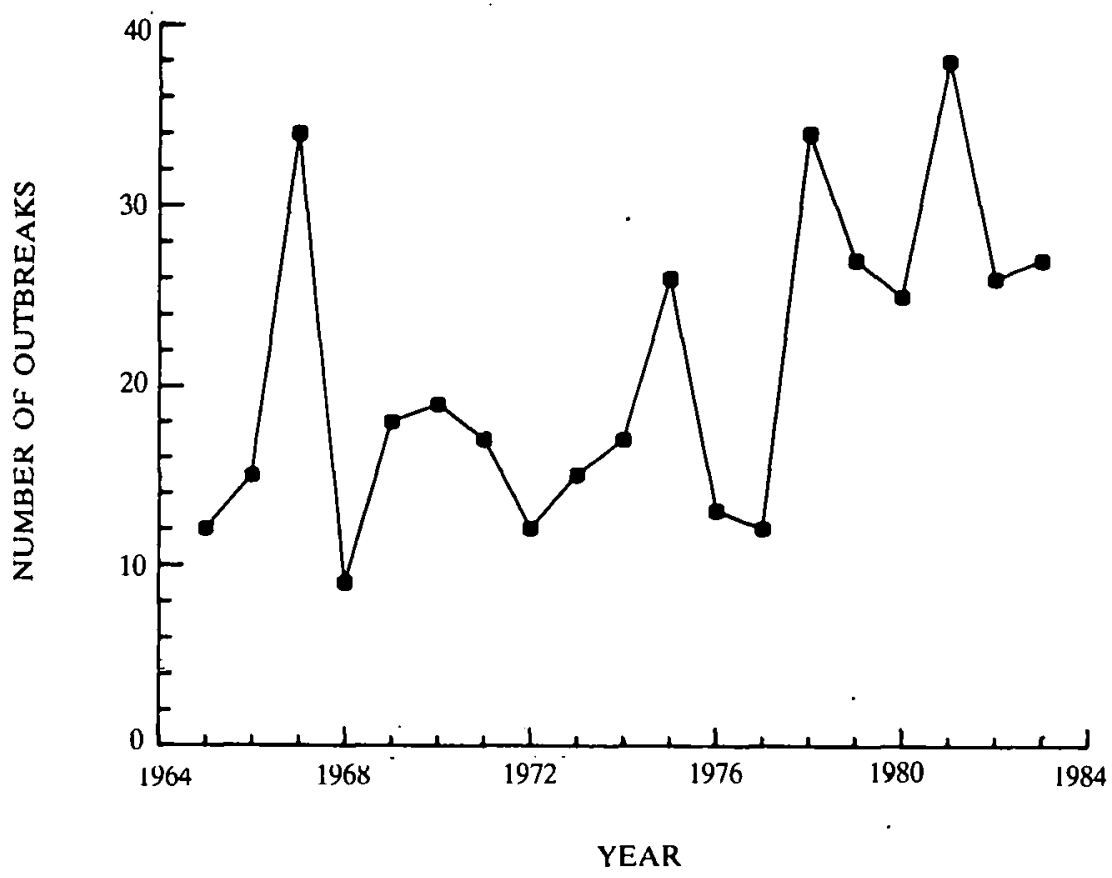

Fig.2. - The number of outbreaks of Opisina arenosella reported annually to the Coconut. Research Institute in 1965-83.

TABLE III. The numbers of estates affected by Opisina arenosella damage

\begin{tabular}{lccccc}
\multicolumn{7}{c}{ Severity of attack* } \\
\hline Province & I & II & III & IV & Totals \\
\hline Southern & 4 & 6 & 7 & 37 & 54 \\
Eastern & 5 & 3 & 2 & 38 & 48 \\
North-Western & 2 & 1 & 6 & 28 & 37 \\
Western & 4 & 1 & 0 & 12 & 17 \\
Others & 0 & 0 & 0 & 3 & 3 \\
\hline Totals & 15 & 11 & 15 & 118 & 159 \\
\hline
\end{tabular}

-The severity of attack is classified in four catcgories: catcgory 1: maximum interval between outbreaks is five years; category II: maximum interval is ten years; category III: maximum interval is 15 years; catcgory IV: only a single outbreak recorded. 
P. A. C. R. PERERA, M. P. HASSELL and H. C. J. GODFRAY
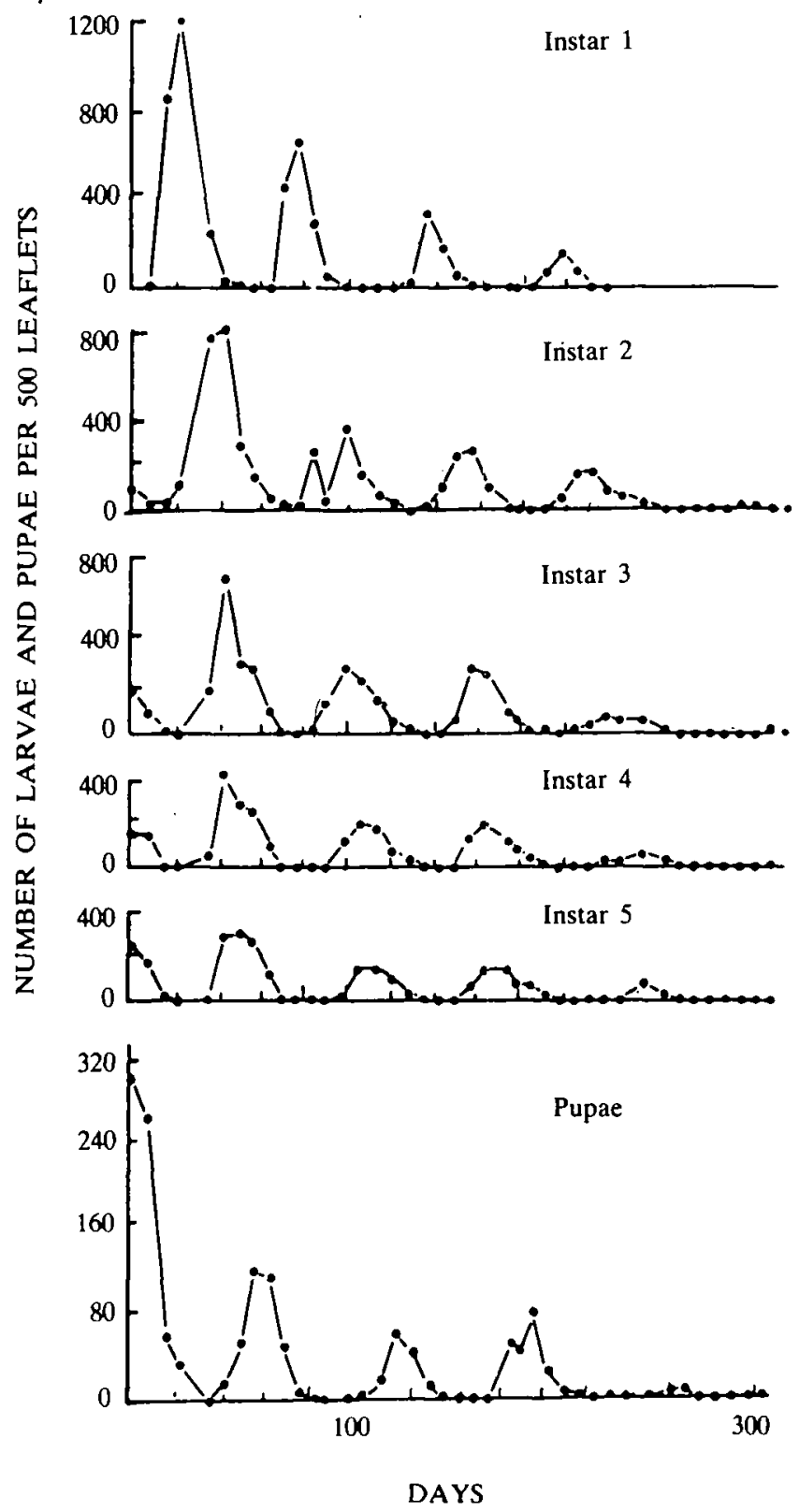

Fig.3. - Weekly population samples of different life cycle stages of Opisina arenosella from Site A. 

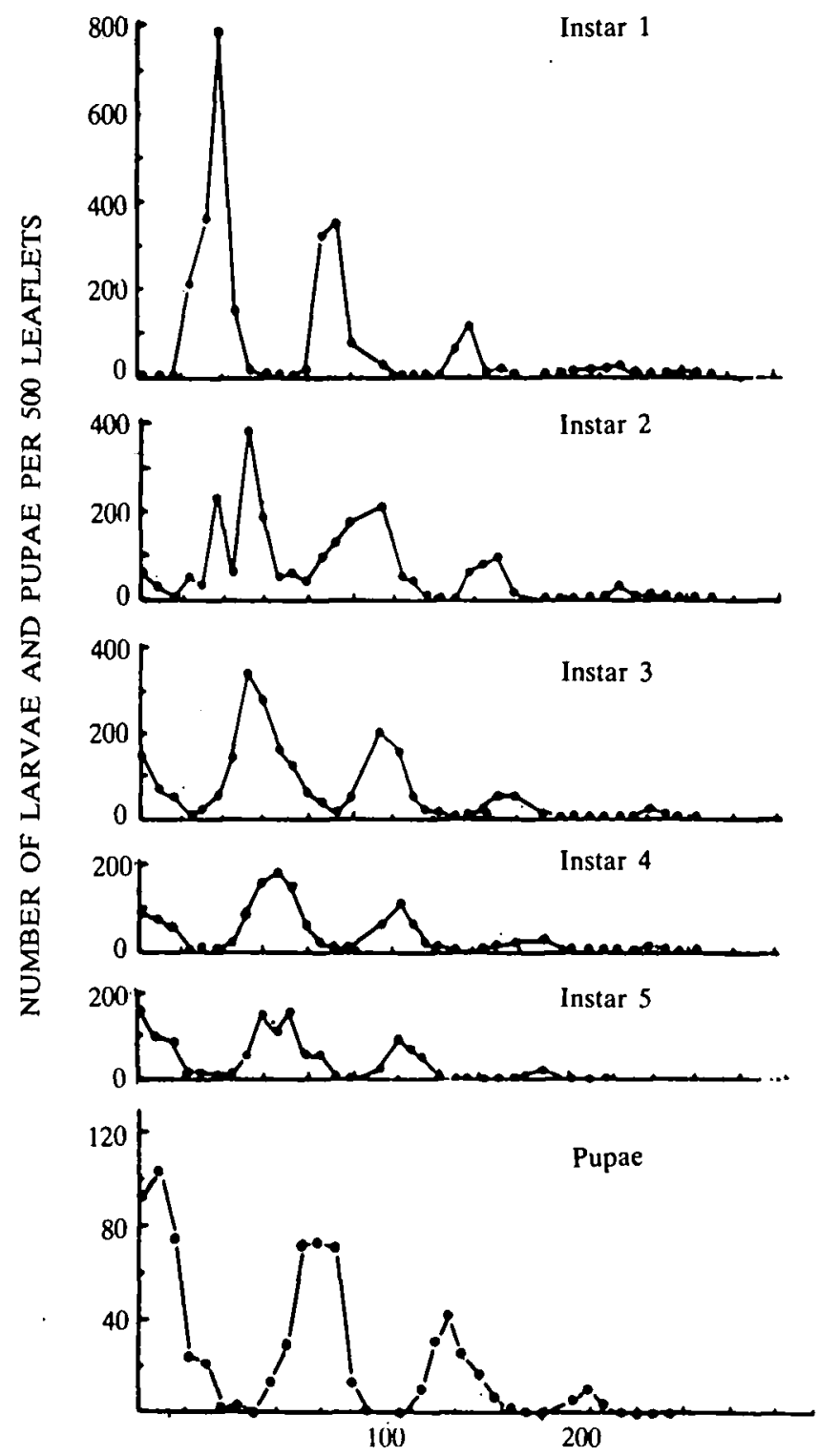

DAYS

Fig. 4. - Weekly population samples of different life cycle stages of Opisina arenosella from Site B. 
P. A. C. R. PERERA, M. P. HASSELL and H. C. J. GODFRAY
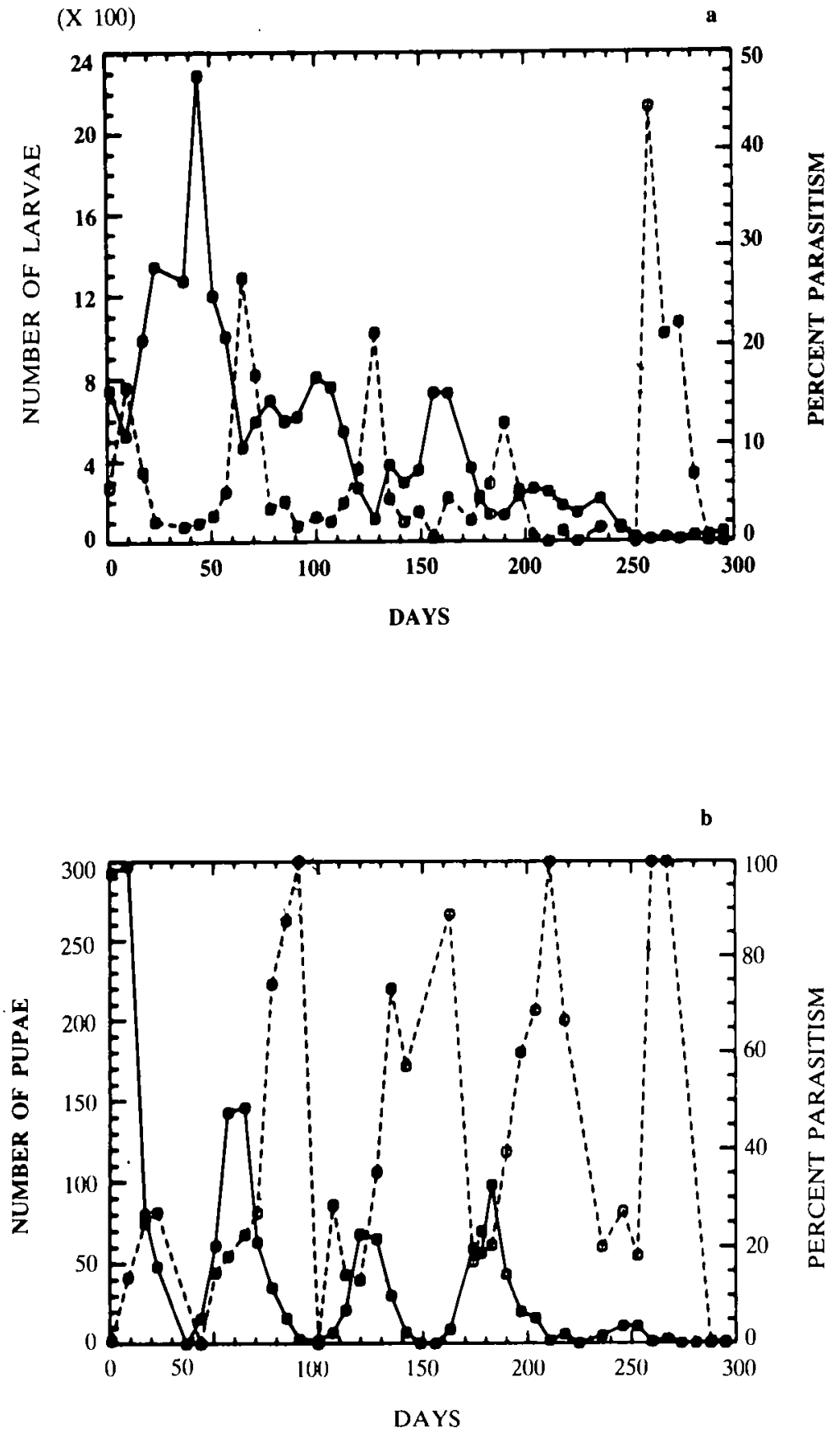

Fig. 5. - Population densities of Opisina arenosella and parasitism per 200 leaflets from Site A. (a) The number of larvae (solid line) and percentage larval parasitism (dashed line); (b) the number of pupae (solid line) and percentage pupal parasitism (dashed line). 


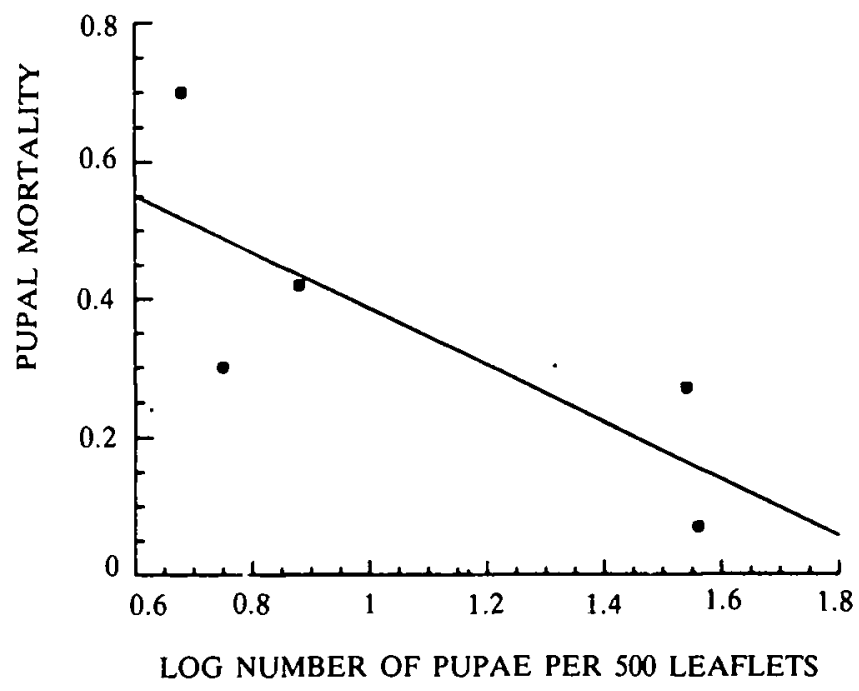

Fig.6. - The relationship between pupal mortality (expressed as $k$ values) of Opisina arenosella and $\log _{10}$ of the density of fifth-instar larvae. The data are described by the line $\mathrm{Y}=0.80-0.41 X(P<0.15)$.

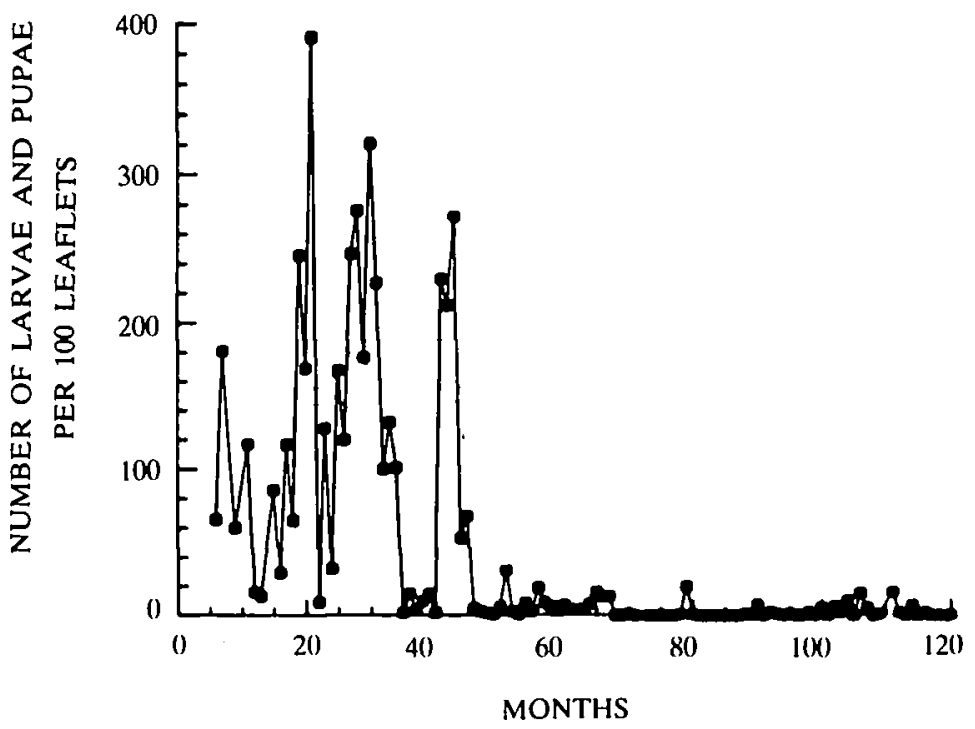

Fig. 7. - Monthly counts of Opisina arenosella alt Site C. 
a

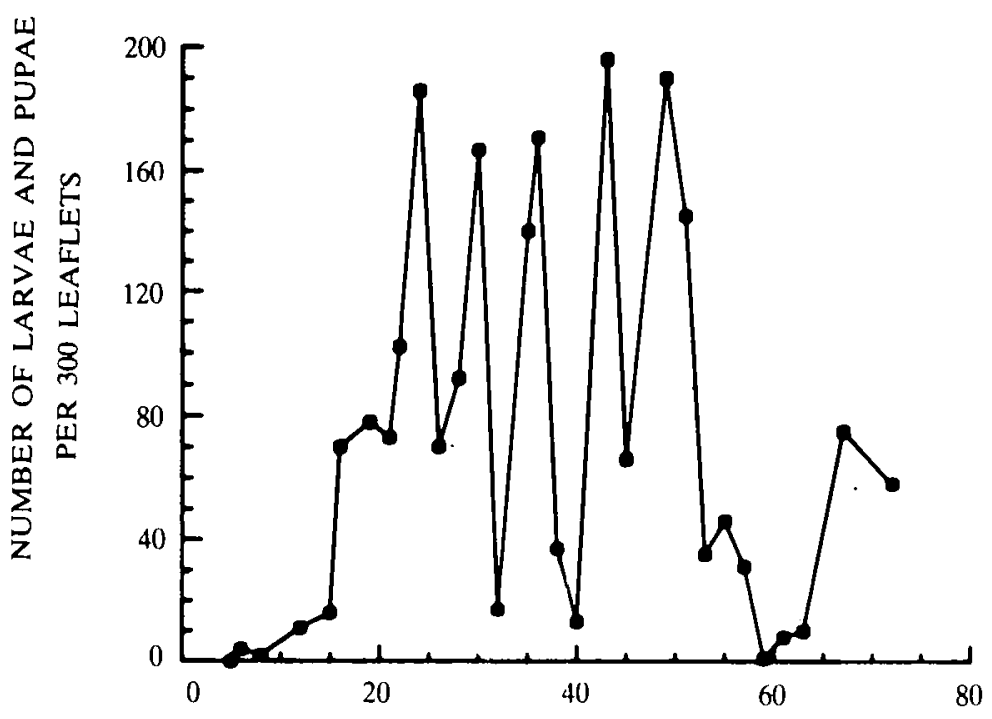

MONTHS

b

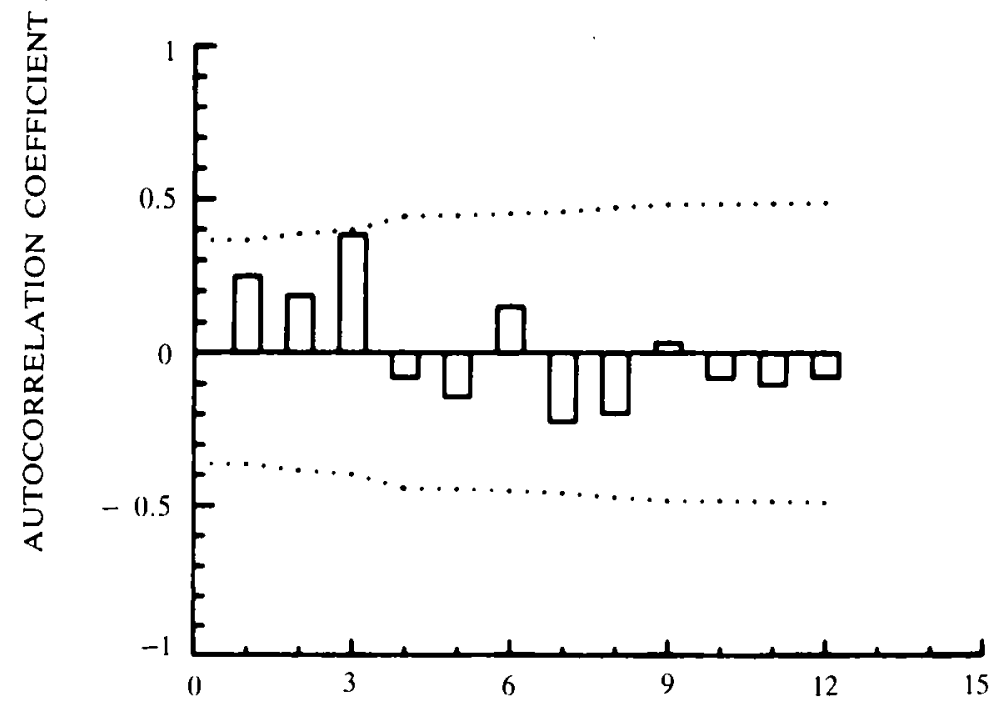

TIME SERIES LAG (TWO-MONTH UNITS)

Fig. 8. - (a) Bimonthly counts of Opisina arenosella at Site D. (b) Autocorrelation analysis of the population trajectory shown in (a) (the dotted line indicates a significant $(P<0.05)$ value of the autocorrelation coefficient). 


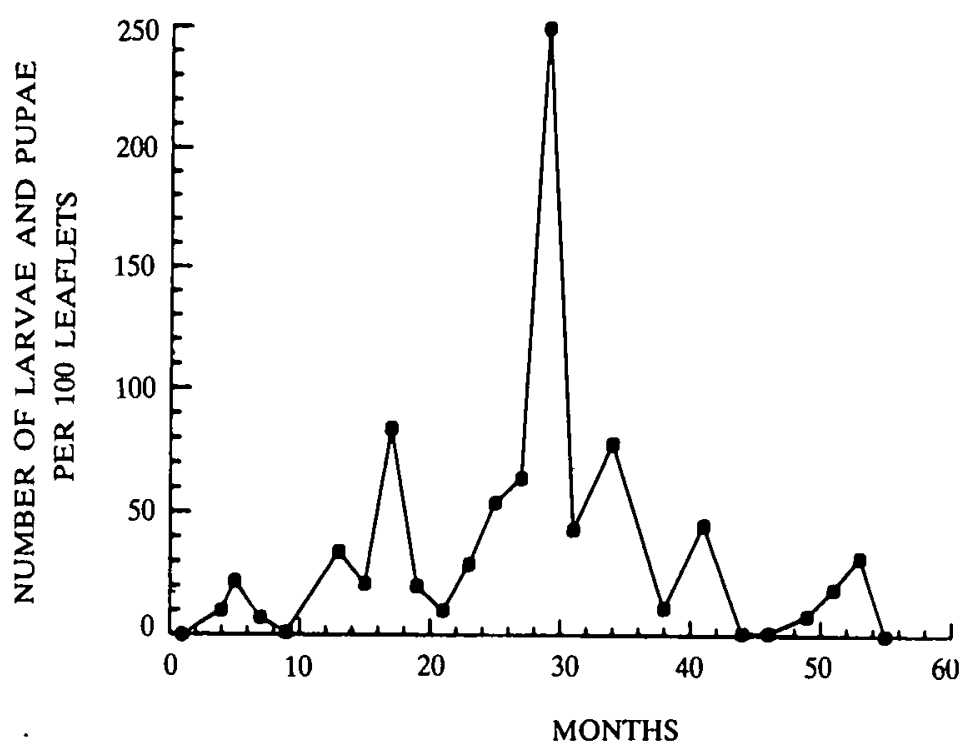

Fig. 9. - Bimonthly counts of Opisina arenosella from Site E.

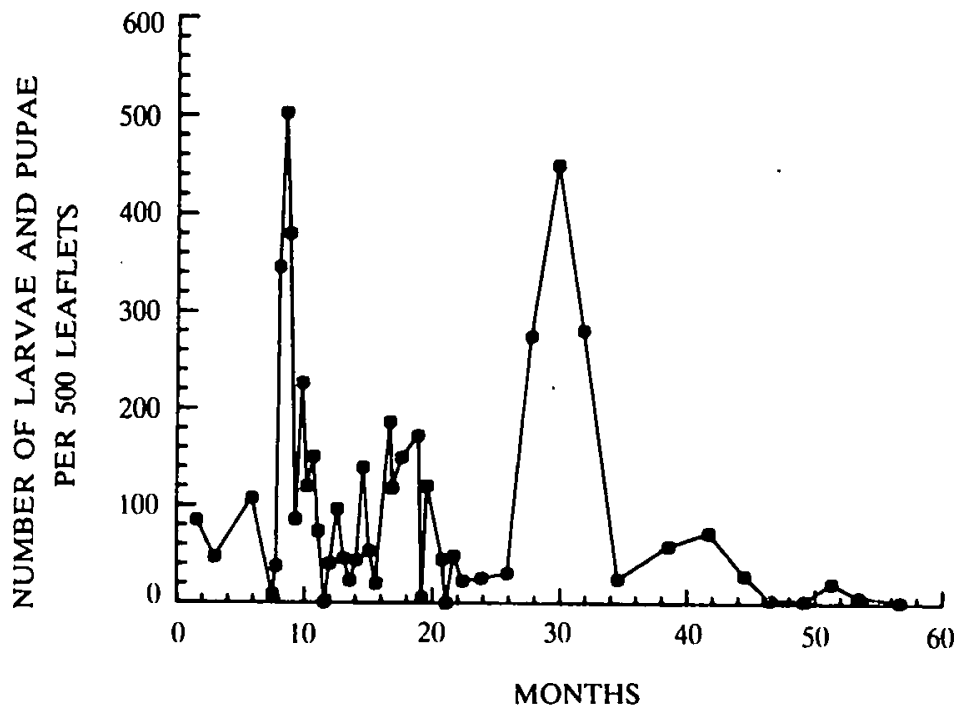

Fig. 10 - Counts of Opisina arenosella from Site F; bimonthly coumts were caken throughour the sampling period but, in addition, the results of some more frequent sampling over part of the period have been included. 


\section{P. A. C. R. PERERA, M. P. HASSELL and H. C. J. GODFRAY}

Table IV. Correlations between the numbers of outbreaks of Opisina arenosella per year in different provinces in 1965-85

(but only to 1983 in Eastern Province)

\begin{tabular}{|c|c|c|c|c|}
\hline & Southern & Eastern & North-Western & Western \\
\hline Southern & & $0.81^{* *}$ & 0.05 & 0.02 \\
\hline Eastern & & & -0.24 & 0.21 \\
\hline North-Western & & & & 0.01 \\
\hline
\end{tabular}

${ }^{* *}$ Significant at $\mathrm{P}<0.001$; other points not significant $(\mathrm{P}>0.1)$.

Site $C$, monthly samples over ten years

The results from the population survey at Site $C$ are shown in Fig. 7. Pest populations remained high for the first 3.5 years of sampling and then dropped to low levels. The sampling interval was approximately half a host generation and the wide fluctuations between successive samples probably reflects the discrete generation structure* of the population.

Sites $D-F$, bimonthly samples over 5-7 years

Figs $8 \mathrm{a}, 9$ and 10 show the results of the sampling at Sites D-F. The two-month sampling interval makes it impossible to detect generation cycles. At all sites, there were considerable population fluctuations, and time series analysis at Sites $E$ and $F$ revealed no discernible pattern. At Site $D$, however, a significant positive autocorrelation with period six months was discovered (Fig. 8b).

\section{DISCUSSION}

Five principle conclusions are drawn from the results presented here. (1) $O$. arenosella is an outbreak pest of coconut in Sri Lanka, and infestations occur in all major coconut-growing regions. (2) The number of infestations per year in different geographical regions are sometimes correlated, suggesting a common triggering mechanism. (3) During outbreaks, pest populations show approximately discrete generations (called by some authors single-stage population behaviour (e.g. Tothill er al., 1930; Taylor, 1937)). (4) Parasitism tends to increase towards the end of an outbreak, tending to make pupal parasitism, in particular, inversely density-dependent. (5) There is evidence that some $O$. arenosella populations show cycles of period. six months.

There are a number of questions on the population dynamics of $O$. arenosella left unanswered. For example, the nature of non-outbreak populations is unclear because of the great difficulty in sampling low densities of the pest in tall palms. It is thus possible that $O$. arenosella is distributed at low densities throughout the coconut-growing areas of Sri Lanka and maintained at these levels by natural enemies, particularly parasitic wasps. This view is supported by the increase in parasitism towards the end of an outbreak (Fig. 5) and by the substantial parasitism observed from some preliminary sampling of low density populations (H. C. J. Godfray, unpublished). Outbreaks would then occur following a breakdown in the regulation by natural enemies. Alternatively, $O$. arenosella may be a 'fugitive species'. with infestations arising when migrants establish new colonies in previously 


\section{Population Dynamics of the Coconut Caterpillar}

uninhabited areas. These then persist until driven extinct by natural enemies or human control measures (Murdoch et al., 1985). Population dynamics intermediate between these two extremes is, of course, possible (Waage \& Greathead, 1988; May \& Hassell, 1988), but we believe the first alternative is the more realistic since it is possible to find $O$. arenosella at very low densities both in non-outbreak areas and in other areas between outbreaks.

If parasitoids do indeed maintain $O$. arenosella populations at low densities, there is the interesting question of how this regulation is disrupted, leading to outbreaks where the pest shows approximately discrete generations. Again, it is useful to consider two alternative explanations. First, suppose that for some reason, probably climatic, all host stages are destroyed except for a resistant stage, perhaps the pupae. Since the parasitoids of $O$. arenosella have generation times shorter than that of their host (Cock \& Perera, 1987), any parasitoids that were not destroyed with the susceptible hosts will emerge to find no suitable host stages for parasitism. The host population will then be simultaneously synchronized and released from its parasitoids. Populations will increase, and an outbreak will develop. Slowly, the discreteness of the host generations will break down due to random variation in the length of the life cycle until invading parasitoids are again able to reproduce and maintain themselves on the host population and begin to bring the population back to endemic levels. Mechanisms of this sort have been proposed to explain single-stage outbreaks of a number of pests (Tothil et al., 1930; Taylor, 1937).

An alternative explanation does not require catastrophic synchronization of the host population. Godfray \& Hassell (1987) developed an age-structured model for a host-parasitoid interaction in an aseasonal environment. They found two types of population behaviour at equilibrium, one with approximately discrete generations and the other with continuous generations. Cycles of one generation's period were particularly likely when the life cycle of the parasitoid was about half that of the host. Perturbation of a population exhibiting either discrete or continuous generations can give rise to fluctuations reminiscent of a 'one-stage' outbreak. However, whilst a continuous generation population quickly returns to its equilibrium, a discrete generation population takes far longer, and recurrent outbreaks at intervals of approximately four generations are predicted. Encouragingly, there is limited evidence fron the long-term sampling of cycles of approximately six-months period (= four generations), as predicted by the model. 'These could also be caused by the biannual monsoons in those regions, and it will be difficult to disentangle these different possible causes, especially since intrinsic cycling mechanisms will frequently 'lock into' extrinsic cycles (Nisbet \& Gurney, 1982):

The available evidence, however, does not point to catastrophic synchronization being responsible for the one-stage outbreaks. Outbreaks are never perfectly synchronized, and parasitoids are normally present throughout the outbreak. It thus seems more likely that outbreaks are caused by the perturbation of an endemic equilibrium. In this case, it is predicted that endemic populations should be found to display discrete generation behaviour, thus accounting for the severity of the outbreaks.

Finally, we turn to control measures and ask in the light of the interpretation above, (1) whether outbreaks can be predicted and (2) what should be done when they occur? The correlations between the frequencies of outbreaks in different 


\section{P. A. C. R. PERERA, M. P. HASSELL and H. C. J. GODFRAY}

provinces suggest that the main source of perturbations leading to pest problems is climatic. Whether the effects of climate act directly on the insect population, or indirectly via the host-plant is not known; the performance of $O$. arenosella larvae is certainly affected if the host-plant is subject to nutrient or water stress (M. E. Cammell \& M. J. Way, pers. comm.). If, as is suggested, outbreaks decline as parasitism builds up, one of the best control measures may be to do nothing at all. Control measures that also kill parasitoids are obviously likely to hamper the return of the pest population to its endemic equilibrium. Even control measures that have little or no effect on the parasitoids may be counterproductive if they disrupt the age-structure of the host population. Further studies on the dynamics of populations at low, endemic levels are needed before firm advice can be given on whether to take control measures and, if so, which will be the most efficacious.

\section{ACKNOWLEDGEMENTS}

We are very grateful to the Commission of the European Community (CEC contract TSD A266, UK (H) for funding this work. We would also like to thank P. S. Beevor, M. E. Cammell, M. J. W. Cock, P. Kanagaratnam, R. Mahindapala, J. D. Mumford, J. K. Waage and M. J. Way for much help and advice.

\section{REFERENCES}

Alam, M. Z. (1962). A list of insects and mites of Eastern Pakistan. - 107 pp Dacca, East Pakistan, Dep. Agric.

Butani, D. K. (1975). Insect pests of fruit crops and their control - 15: date palm - Pesticides 9, 40-42.

Cock, M. J. W. \& Perera, P. A. C. R. (1987). Biological control of Opisina arenosella Walker (Lepidoptera, Oecophoridae).-Biocontrol News \& Inf. 8,283-310.

Davis, T.A. \& Sudasrip, H. (1982). Causes for the defoliation of coconuts in Indonesia. - Indonesian Agric. Res. Dev. J.4, 8-29.

De Mel, C. N. E. J. (1927). Pests and diseases of coconuts in the North-Western Province. - Trop. Agriculturist Ceylon 68, 252-256.

Dharmaraju, E. (1963). Biological control of coconut leaf caterpillar (Nephantis serinopa Meyrick) in Ceylon. - Bull. Cocon. Res. Inst. Ceylon no. 21, 46 pp.

Ghosh, C.C. (1924). Oryctes rhinoceros and other important palm pests in Burma. pp. 99-103 in Report of the Proceedings of the 5th Entomology Meeting, Pusa, February 1923. - Calcutta.

Godfray, H. C. J. \& Hassell, M. P. (1987). Natural enemies may be a cause of discrete generations in tropical insects. - Nature, Lond. 327, 144-147.

Green, E. E. (1898). A coconut palm catepillar. - Trop. Agriculturist Ceylon 26, 298-308.

Hutson, J. C. (1922). Some preliminary notes on the coconut caterpillar in Ceylon. Bull. Dep. Agric. Ceylon no. 58,12 pp.

Jayaratnam, T. J. (1941). A study of the control of the coconut caterpillar (Nephantis serinopa Meyr.) in Ceylon with special reference to its eulophid parasite, Trichospilus pupivora Ferr. - Trop. Agriculturist Ceylon 96, 3-31.

Kanagaratnam, P. (1976). Annual report of the Crop Protection Division for 1975. Ceylon Coconut Q. 27, 36-41. 
Kanagaratnam, P. \& Pinto, J. L. J. G. (1985). Effect of monocrotophos on the leaf eating caterpillar, Opisina arenosella Walk. when injected into the trunk of the coconut palm. - Cocos 3, 9-15.

Lever, R. J. A. W. (1969). Pests of the coconut palm. - 190 pp. Rome, FAO (FAO Agric. Stud. no. 77)

Manjunath, T. M. (1985). Coconut black-headed caterpillar on banana and coconut. - Pl. Prot. Bull. F.A.O.33, 71-72.

May, R. M. Hassell, M. P. (1988). Population dynamics and biological control. - in Way, M. J. \& Wood, R. (Eds). Biological control of pests, pathogens and weeds: developments and prospects. - Phil. Trans. R. Soc. Lond. B 318, 129-169.

Mohamed, U. V. K., Abdurahimen, U. C. \& Remadevi, O. K. (1982). Coconut caterpillar and its natural enemies. - Kerala, India, Dep. Zool., Univ. Calicut (Zool. Monogr. no. 2).

Murdoch, W. W., Chesson, J. \& Chesson, P. L.(1985). Biological control in theory and practice. - Am. Nat. 125, 343-366.

Nadarajan, L. \& Channabasavanna, G. P. (1981). Trunk injection of systemic insecticides against the coconut black headed caterpillar Nephantis serinopa Meyrick ( Pepidoptera : Cryptophasidae). - Oleagineux 36, 239-245.

Nirula, K. K. (1956). Investigations on the pests of coconut palm. Part III. Nephantis serinopa Meyrick. - Indian Cocon.J. 9, 101-131, 174-201.

Nisbet, R. M. \& Gurney, W. S. C. (1982). Modelling fluctuating populations. - 379 pp. Chichester, UK, Wiley.

Perera, P. A. C. R. (1987). Studies on Opisina arenosella Walker and its natural enemies in Sri Lanka. - Ph.D. thesis, Univ. London.

Philip, B. M., Mathai, S. \& Jacob, A. (1982). A nuclear polyhedrosis of the black headed caterpillar, Nephantis serinopa Meyrick (Lepidoptera: Cryptophasidae). Curr. Sci. 51, 611.

Ramachandran, C. P., Ponnamma, K. N., Koya, K. M. A. \& Kurian, C. (1979). The coconut leaf-eating caterpillar, Nephantis serinopa Meyrick, a review. - Philipp. J. Cocon. Stud. 4, 9-17.

Rohitha, B. H. (1982). Report of the Crop Protection Division for 1981. - Ceylon Cocon. Q.33, 57-60.

Sundaramurthy, V. T. \& Santhanakrishan, K. (1979). Morphogenetic effects of diflubenzuron, an inhibitor of chitin deposition, on the coconut black-headed caterpillar (Nephantis serinopa Myer.) - Pestic. Sci. 10, 147-150.

Talati, G. M. \& Kapadia, M. N. (1984). Influence of host plants on larval development, longevity and fecundity of Nephantis serinopa. Meyrick (Lepidoptera:Cryptophasidae). - Gujarat Agric. Univ. Res. J. 9 (2), 57-59.

Taylor, T. H. C. (1937). The biological control of an insect in Fiji. -239 pp. London Imp. Inst. Ent.

Tothill, J. D., Taylor, T. H. C. \& Paine, R. W. (1930). The coconut moth in Fiji. 269 pp. London, Imp. Bur Ent.

Waage, J. K. \& Greathead, D. J. (1988). Biological control: challenges and opportunities. - in Way, M. J. \& Wood, R. (Eds.). Biological control of pests, pathogens and weeds: developments and prospects.- Phil. Trans. R. Soc. Lond B. 318, 111-128. 